Editorial

\title{
Commemorative Issue in Honor of Professor Calvin H. Bartholomew's 75th Birthday
}

\author{
Morris D. Argyle ${ }^{\circledR}$
}

Brigham Young University, Chemical Engineering Department, Provo, UT 84602, USA; mdargyle@byu.edu; Tel.: +1-801-422-6293

Received: 6 November 2018; Accepted: 8 November 2018; Published: 9 November 2018

check for updates

\begin{abstract}
This editorial is written to recognize Professor Emeritus Calvin H. Bartholomew, who celebrated his 75th birthday in 2018, and to introduce the commemorative issue of Catalysts compiled in his honor. Following a brief biography that celebrates the career and contributions of Professor Bartholomew, the nine articles that make up the special issue are briefly reviewed. Dr. Bartholomew is an eminent researcher, an outstanding educator, mentor, and friend.
\end{abstract}

Keywords: Calvin H. Bartholomew; heterogeneous catalyst deactivation; Fischer-Tropsch

\section{Introduction}

Serving as editor of this special issue in honor of Professor Calvin H. Bartholomew (see Figure 1) truly has been a privilege. Professor Bartholomew, or Dr. B as he is known to his students, is continuing his distinguished career in heterogeneous catalysis. He has been a mentor and a friend to multitudes. This special issue is a small token of the respect he has gained from his peers and students.

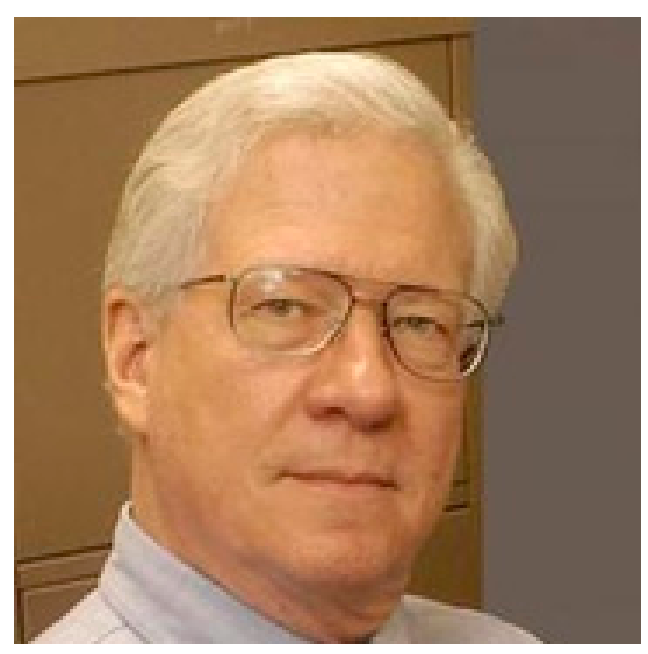

Figure 1. Professor Emeritus Calvin H. Bartholomew.

\section{Brief Biography}

Calvin H. Bartholomew, Professor Emeritus of Chemical Engineering at Brigham Young University (BYU), has taught and mentored students at both BYU and across the world in catalysis, materials, and catalyst deactivation for 45 years. After graduating with his bachelor's degree from BYU, he performed his PhD research on "Surface Composition and Chemistry of Supported Platinum-Iron Alloy Catalysts" [1] at Stanford University under the direction of the incomparable Michel Boudart. Upon graduation from Stanford, he worked for Corning Glass Works as Senior Chemical Engineer 
in Automotive Emissions Control and Surface Chemistry Research. He then began his career as a professor in the Chemical Engineering Department at BYU in 1973, where he built the Catalysis Laboratory while advising over 34 graduate students and dozens more undergraduates in his research. In professional service, he served as president of the Central Utah Section of the American Chemical Society and the California Catalysis Society, is active in the American Institute of Chemical Engineers, and was a founder of both the Rocky Mountain Fuel Society and the Western States Catalysis Club, which currently exists as the Rocky Mountain Catalysis Society. He received the Karl G. Maeser Research Award, which is the highest honor awarded annually to a researcher at BYU, and was chosen as the Engineering College Outstanding Faculty member. Most recently, he was named as the Honorary Chair of the North American Catalysis Society Meeting held in Denver, CO in 2017.

Since receiving emeritus status in 2009, Professor Bartholomew has continued his premier research and mentoring of faculty, graduate students, and undergraduates. He continues to be active in the field of heterogeneous catalysis as a recognized authority on Fischer-Tropsch synthesis and catalyst deactivation. He is also noted for his work with Mössbauer spectroscopy, $\mathrm{NO}_{\mathrm{x}}$ decomposition with automotive catalysts, and authoritative works on supported nickel catalysts and their poisoning by sulfur. He has co-authored over 140 journal articles, which have received over 10,000 citations; 20 chapters/reviews; six books; and six patents. In addition to his employment at Corning Inc., he has also worked for UnoCal, Sandia National Labs, and Lawrence Livermore Laboratory and consulted with more than 80 company clients, including a dozen plus start-up gas-to-liquids companies. Furthermore, he has been the principal motivator for the development of advanced supports and Fischer-Tropsch catalysts at Cosmas Inc.

Finally, in addition to teaching countless university courses over 36 years on kinetics, catalysis, catalyst deactivation, air pollution control, creativity, and engineering materials (see Figure 2), Professor Bartholomew has taught short courses on "Heterogeneous Catalysis", "Fischer-Tropsch Synthesis", and "Catalyst Deactivation" to more than 750 professionals from industry and academe. In down times during these courses, he is known to break into song in his beautiful, resonant voice. He is a scholar, a gentleman, and a friend. The other authors who contributed to this special issue and I wish him and his family (Cal and his wife Karen have five children, nine grandchildren and two great grandchildren) many more years of happiness and scholarly productivity.

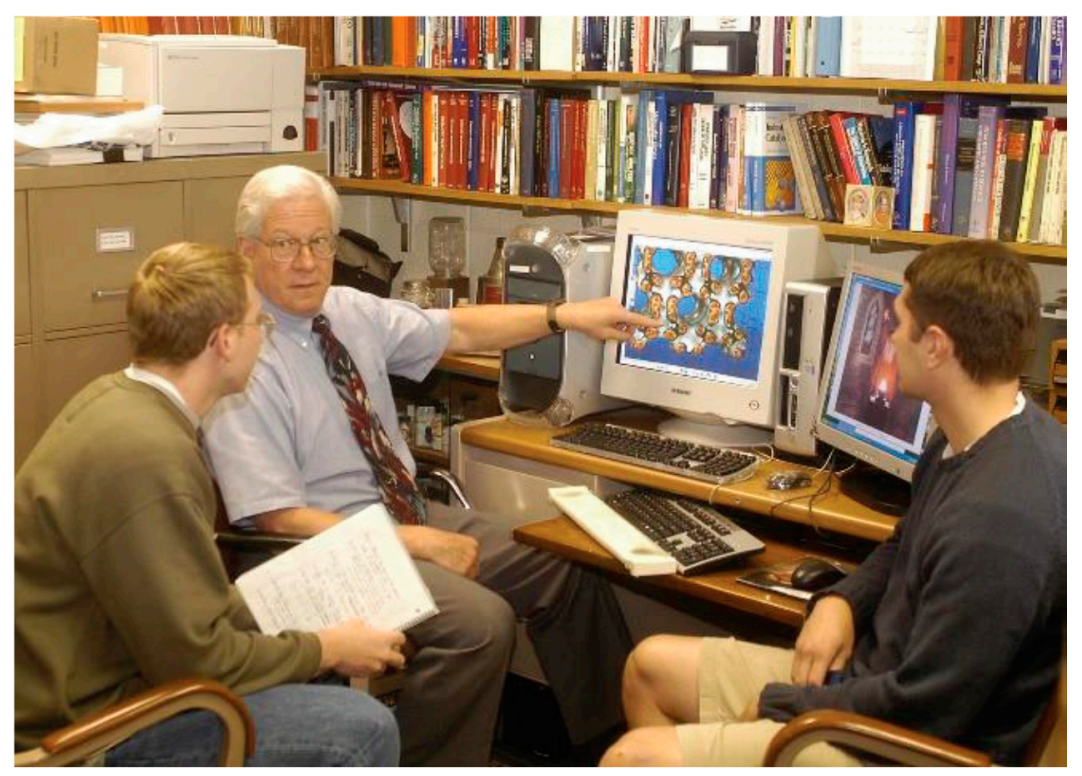

Figure 2. Professor Bartholomew with students. 


\section{Highlights of Professor Bartholomew's Research}

As a few selected highlights from his most-cited published works, Dr. Bartholomew has authored several definitive reviews on catalyst deactivation [2,3], with special emphasis on sulfur poisoning [4], carbon deposition [5], and sintering [6,7], for which he championed the use of generalized power law expressions (GPLE) to model the deactivation. GPLE's contain a limiting, steady-state value of activity that is more accurate compared to the more common assumption of a simple power law expression, which takes the final activity of the catalyst as zero. He has been active in both cobalt [8] and iron [9] based Fischer-Tropsch catalyst research. More recently, he developed the slit pore model to characterize the pore size distribution of mesoporous catalytic support materials that is more accurate than conventional models [10]. Finally, as a major contribution to the field, he published a leading handbook and textbook, Fundamentals of Industrial Catalytic Processes, with his long-time collaborator, Dr. Robert Farrauto [11].

\section{The Contents of the Special Issue}

The nine contributions to this special issue come from former students, collaborators, colleagues, and respected peers. Keyvanloo et al.'s paper on Fischer-Tropsch catalysis [12] honors Professor Bartholomew's extensive contributions to this area. Hallac et al.'s spectroscopic study on iron-based water gas shift catalysts [13] hearkens back to Professor Bartholomew's graduate work with iron. Seeburg et al.'s paper on methane combustion catalyst stability [14] and Ruelas-Leyva and Fuentes work on chiral catalyst deactivation [15] fit with the constant theme of catalyst deactivation in Dr. Bartholomew's work. Tu et al.'s contribution on palladium catalysts supported on titania for hydrogen peroxide production [16] also touches on themes of this metal and support in Dr. Bartholomew's work. Ha et al.'s paper on nickel catalysts for (dry) methane reforming and carbon deactivation [17] go back to Dr. Bartholomew's early work on both nickel and methane reforming. Türks et al.'s work on $\mathrm{CO}_{2}$ methanation on nickel catalysts builds on these major themes of Dr. Bartholomew's research [18]. Finally, the contribution by Xiang et al. [19], whose corresponding author is Dr. Bartholomew's long-time collaborator, Bob Farrauto [20], echoes some of his earliest work on environmental catalysts. In summary, this special issue covers much of the breadth and points to the depth of Professor Emeritus Calvin H. Bartholomew's illustrious career. We thank him for his admirable example and honor him for his lasting contributions.

Conflicts of Interest: The author declares no conflict of interest.

\section{References}

1. Bartholomew, C.H. Surface Composition and Chemistry of Supported Platinum-Iron Alloy Catalysts. Ph.D. Thesis, Stanford University, Palo Alto, CA, USA, 1972.

2. Bartholomew, C.H. Mechanisms of catalyst deactivation. Appl. Catal. A 2001, 212, 17-60. [CrossRef]

3. Argyle, M.D.; Bartholomew, C.H. Heterogeneous catalyst deactivation and regeneration: A review. Catalysts 2015, 5, 145-269. [CrossRef]

4. Bartholomew, C.H. Carbon Deposition in Steam Reforming and Methanation. Catal. Rev. Sci. Eng. 1992, 24, 67-112. [CrossRef]

5. Bartholomew, C.H.; Agrawal, P.K.; Katzer, J.R. Sulfur Poisoning of Metals. Adv. Catal. 1982, 31, 135-242. [CrossRef]

6. Bartholomew, C.H. Sintering kinetics of supported metals: New perspectives from a unifying GPLE treatment. Appl. Catal. A 1993, 107, 1-57. [CrossRef]

7. Bartholomew, C.H. Sintering Kinetics of Supported Metals: Perspectives from a Generalized Power Law Approach. In Studies in Surface Science and Catalysis; Delmon, B., Froment, G.F., Eds.; Elsevier: Amsterdam, The Netherlands, 1994; Volume 88, pp. 1-18. ISBN 978-0-444-81682-5. [CrossRef]

8. Reuel, R.C.; Bartholomew, C.H. The stoichiometries of $\mathrm{H}_{2}$ and $\mathrm{CO}$ adsorptions on cobalt: Effects of support and preparation. J. Catal. 1984, 85, 78-88. [CrossRef] 
9. $\mathrm{Xu}, \mathrm{J}$;; Bartholomew, C.H. Temperature-programmed hydrogenation (TPH) and in situ Mössbauer spectroscopy studies of carbonaceous species on silica-supported iron Fischer-Tropsch catalysts. J. Phys. Chem. B 2005, 109, 2392-2403. [CrossRef] [PubMed]

10. Huang, B.; Bartholomew, C.H.; Woodfield, B.F. Improved calculations of pore size distribution for relatively large, irregular slit-shaped mesopore structure. Microporous Mesoporous Mater. 2014, 184, 112-121. [CrossRef]

11. Bartholomew, C.H.; Farrauto, R. Fundamentals of Industrial Catalytic Processes, 2nd ed.; Wiley: Hoboken, NJ, USA, 2006; pp. 1-966. ISBN 978-047145713-8.

12. Keyvanloo, K.; Huang, B.; Okeson, T.; Hamdeh, H.H.; Hecker, W.C. Effect of Support Pretreatment Temperature on the Performance of an Iron Fischer-Tropsch Catalyst Supported on Silica-Stabilized Alumina. Catalysts 2018, 8, 77. [CrossRef]

13. Hallac, B.B.; Brown, J.C.; Stavitski, E.; Harrison, R.G.; Argyle, M.D. In Situ UV-Visible Assessment of Iron-Based High-Temperature Water-Gas Shift Catalysts Promoted with Lanthana: An Extent of Reduction Study. Catalysts 2018, 8, 63. [CrossRef]

14. Seeburg, D.; Liu, D.; Radnik, J.; Atia, H.; Pohl, M.-M.; Schneider, M.; Martin, A.; Wohlrab, S. Structural Changes of Highly Active $\mathrm{Pd} / \mathrm{MeOx}(\mathrm{Me}=\mathrm{Fe}, \mathrm{Co}, \mathrm{Ni})$ during Catalytic Methane Combustion. Catalysts 2018, 8, 42. [CrossRef]

15. Ruelas-Leyva, J.P.; Fuentes, G.A. Chiral Catalyst Deactivation during the Asymmetric Hydrogenation of Acetophenone. Catalysts 2017, 7, 193. [CrossRef]

16. Tu, R.; Li, L.; Zhang, S.; Chen, S.; Li, J.; Lu, X. Carbon-Modified Mesoporous Anatase/ $\mathrm{TiO}_{2}$ (B) Whisker for Enhanced Activity in Direct Synthesis of Hydrogen Peroxide by Palladium. Catalysts 2017, 7, 175. [CrossRef]

17. Ha, Q.L.M.; Armbruster, U.; Atia, H.; Schneider, M.; Lund, H.; Agostini, G.; Radnik, J.; Vuong, H.T.; Martin, A. Development of Active and Stable Low Nickel Content Catalysts for Dry Reforming of Methane. Catalysts 2017, 7, 157. [CrossRef]

18. Türks, D.; Mena, H.; Armbruster, U.; Martin, A. Methanation of $\mathrm{CO}_{2}$ on $\mathrm{Ni} / \mathrm{Al}_{2} \mathrm{O}_{3}$ in a Structured Fixed-Bed Reactor-A Scale-Up Study. Catalysts 2017, 7, 152. [CrossRef]

19. Martinelli, M.; Jacobs, G.; Graham, U.M.; Davis, B.H. Methanol Steam Reforming: Na Doping of Pt/YSZ Provides Fine Tuning of Selectivity. Catalysts 2017, 7, 148. [CrossRef]

20. Xiang, W.; Han, X.; Astorsdotter, J.; Farrauto, R. Catalysts Promoted with Niobium Oxide for Air Pollution Abatement. Catalysts 2017, 7, 144. [CrossRef]

(C) 2018 by the author. Licensee MDPI, Basel, Switzerland. This article is an open access article distributed under the terms and conditions of the Creative Commons Attribution (CC BY) license (http://creativecommons.org/licenses/by/4.0/). 